5. Волошина Л. Ельза: притча про любов. Украӥнський письменник. 2006. Вип. 3. С. 73-88.

6. Когут О.В. Архетипні сюжети та образи в сучасній українській драматургії: монографія/ за ред. О.В. Когут. Рівне: НВУГП, 2010. 440 с.

DOI https://doi.org/10.30525/978-9934-26-073-5-1-29

\title{
РОМАН «УТОПЛЕННЯ» ОЕ КЕНДЗАБУРО: МІСЦЕ МИТЦЯ/МИСТКИНІ В ІНТЕРПРЕТАЦЇ̈ КОНЦЕПЦІЇ «ДУХУ ЕПОХИ» НАЦУМО СОСЕКІ
}

\author{
Дудар Я. О. \\ аспірантка кафедри порівняльної філології східних \\ та англомовних країн \\ Дніпровського начіонального університету імені Олеся Гончара \\ м. Дніпро, Украӥна
}

Однією з характерних стильових рис всієї творчості Ое Кендзабуро $є$ саме семантика наративу покоління. В полі зображення постають як сучасники самого письменника, так і молоді, прийдешні покоління - це тло конфлікту людини і їі часу, що простягається майже на століття i визначає мету художнього зображення японського письменника.

Прийняття та пізнання концепції пізнього стилю Едварда В. Саїда [1] визначило та змінило попередньо встановлені письменником канони власного романного стилю, спонукало до перегляду, вигарто-вування еклектичних естетичних категорій в романі «Утоплення» (『水死』, 2009). В цьому тексті автор/наратор майже повністю трансформується у спостерігача, що фіксує у тексті конфлікт нового покоління та свого власного. Проблема постає не просто у зображенні прагнення жінок до визнання своїх здібностей та сили чоловіками, але вже процес, що відбувається. У тексті відсутні знаки питання чи можуть жінки бути «митцем», тут вони знаходять свою унікальність, тому що вони «мисткині» зі своїми власними і новими творчими підходами. Це вже не просто гендерна проблема сприйняття суспільством інваріанту існування жінки-митця, що не має сталого образу у японській культурі, що має власну та нову мову, інструменти та теми; але й проблема боротьби 3 епохою Сьова, що закарбувала образ чоловіка-митця і його власні художні теми. Роман торкається різниці між історичними періодами 
Японії та в свідомості людей: що є «дух Мейдзі», що є «дух Сьова», що $є$ «дух Хейсей».

Oe/Когіто є митцем епохи Сьова, і він розуміє, що його час вже майже вичерпано: на зміну йому вже прийшли нові митці, і що найважливіше мисткині. Позаду нього лишаються ті ж нерозв'язні соціо-культурні та політичні проблеми, що все ще продовжують впливати на сьогодення японців.

Письменник своїм романом доводить, що насправді зміни починаються з мистецтва, і тому митці - це їх передвісники та рушії.

В трилогії «Дивна Пара» (『おかしな二人組』, 2000-2005) Oe аналізував, в першу чергу, своє минуле та тих, хто пішов з життя, намагаючись знайти причину їх спільного нещастя - i прийшов до висновку, що проблема криється лише в самому поколінні. Ці чоловіки, що завжди були головними героями романів Ое, образами з котрими він міг себе асоціювати, відтворювати себе як художнє альтер-его мали багато спільного: むしろそれは、古義人の世代の男たちに共通の生活 態度かもしれない..... // Можливо, ие все через відношення до життя, що було характерним для чоловіків покоління Когіто [3, с. 42]. Ое був свідком, як ті, кого він знав страждали на самоті, і помирали передчасно, як Місіма Юкіо, його швагер Ітамі Дзюдзо (в результаті трансформований у образ Горо), і він сам.

Роман «Утоплення» чітко презентує змінення ідей попередньої епохи задля побудови кращого майбутнього. Так герой Масао, режисер, що уособлює образ чоловіка-митця ще попередньої епохи, запитує Oе/Когіто：この時代に生きた人はみんな、それに影響を受けたんでし ようか?// Люди, щчо жили в иңю епоху [Мейдзі] - чи були вони під ї̈ виливом? [2, с. 138], апелюючи до відомої концепції іншого японського письменника - Нацуме Сосекі про «дух Мейдзі» (明治の精神) [4] в романі «Серце» (『こつろ』, 1914) [4]. Це питання не має однозначної відповіді для автора і героїв роману. В першу чергу, епоха Мейдзі уособлює реформи в кожній сфері життя нації, відмову від сьогунату та перехід влади до імператора Мацухіто. Це дух усвідомлення власної національної ідентичності в рамках нового часу. Проте, роман Сосекі це зворотна сторона, наповнена відчуттям приреченості, вини і тінню смерті.

Ое створює свого головного героя/нове альтер-его пізнього стилю, Когіто, що особливо в трилогії «Дивна Пара» є залежним від своєї доби, i як не намагається - не може звільнитися від неї. Але в цьому романі молоде покоління, і саме жінок, цікавить чи можуть вони звільнитися від 
впливу своєї доби та попередніх - нав'язаних жорстоких i несправедливих суспільно-культурних норм.

Але, більш важливими питаннями, що хвилює героїв $є$ : хто саме $\epsilon$ носієм духу своєї епохи насправді? - Чи це люди яких більшість? Чи навпаки? Що відбувається з людиною, коли ії епоха закінчується?

Ое, використовуючи Когіто відповідає наступне: 時代から離れて、 周りの人間とはできるだけ無関係に生きようとする人間こそ、その時 代の精神の影響を受けてるんじやないかと思うね。// Розлучаючись зі своєю епохою, такі люди починають жити окремо від свого оточення чи не тому цче відбувається, щзо вони є під впливом духу своєї доби? [2, с. 139]. Для японського письменника відчуття прірви між окремою особистістю та оточенням є ультимативним проявом поетики пізньості, котру він досліджує в своїх останніх текстах. Його головна мета «передати дух доби» (時代の精神の表現をめざす) [2, с. 139], що не зможе вже тривати після його смерті. Епоха закінчується не з офіційним проголошенням, а $з$ життям їі носіїв. Так і Ое говорить, що його не хвилює факт власної смерті як людини, але хвилює смерть як митця своєї доби: <..>死ぬことになれば、自分は時代の精神に殉死するように なもんだ。// Якщуо я помру, иче те ж саме, щчо я вчиню самогубство власному духу епохи [2, с. 139]. Саме це і постає однією з причин, чому він потерпає від незупинного прагнення завершити той перший [останній] роман, що уявляв собі як головний твір життя; того розчарування, коли обставини завадили цьому. Поступово, Когіто приходить до розуміння, що створити роман як він собі його уявляв неможливо, але історія може бути розказана по-іншому, - через мову мисткинь та жінок, що отримали головний голос в його романі.

\section{Література:}

1. Said E. On Late Style: Music and Literature Against the Grain / edited by M. Wood. London: Bloomsbury Publishing Plc. 2006. 208 p.

2. 大江健三郎. 水死. 講談社. 2009. 450ページ.

3. 大江健三郎. 取り替え子. 講談社. 2000. 392ページ.

4. 夏目 漱石. こころ. 文藝春秋. 1996. 478 ページ. 